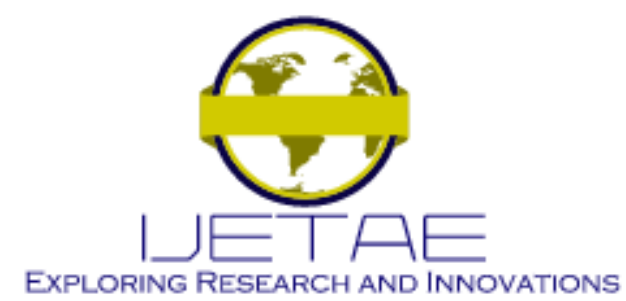

International Journal of Emerging Technology and Advanced Engineering

Website: www.ijetae.com (E-ISSN 2250-2459, Scopus Indexed, ISO 9001:2008 Certified Journal, Volume 12, Issue 02, February 2022)

Manuscript Received: 14 January 2021, Received in Revised form: 11 February 2022, Accepted: 16 February 2022

DOI: 10.46338/ijetae022_18

\title{
Creating a Service-Oriented Information and Educational Space
}

\author{
Dmitry Gennadievich Korneev ${ }^{1}$, Mikhail Samuilovich Gasparian ${ }^{2}$, Aleksandr Viktorovich Gavrilov ${ }^{3}$, \\ Nikita Aleksandrovich Sysoev ${ }^{4}$, Mariya Alekseevna Filyuk ${ }^{5}$ \\ 1,2,3,4,5 lekhanov Russian University of Economics, 117997, Russian Federation, Moscow, Stremyanny lane, 36
}

\begin{abstract}
The current stage of the digitalization of education is associated with the transition to professional standards as a basis for practice-oriented training of competent professionals who can actively function given the constant improvement of various kinds of technology and have a high degree of professional qualification and competitiveness. At present, a vast number of new professions and activities related to digital transformation and re-engineering of traditional business processes are emerging in the labor market. As a response to such a challenge of our time, the highest priority becomes the task of even more in-depth practice-oriented training of highly qualified personnel for the digital economy based on a variety of methods and tools to support learning. The goal of the present study is to develop fundamentally new methods of creating educational programs with consideration of individual requirements and characteristics of students. In this area, the standards developed by the World Wide Web Consortium, such as WSDL, SAWSDL, SOAP, UDDI, WSMO, are used. However, their application in the process of composition and interaction of information and educational services leaves several unresolved issues, which are considered in this article. As a result of the conducted research, the authors attempt to conceptually define the composition and principles of creating ontologies to provide for the search for and subsequent design of services of the information and educational space.
\end{abstract}

Keywords - concept, information and educational environment, ontology, semantic interoperability, serviceoriented architecture.

\section{INTRODUCTION}

Service-oriented architectures are currently being actively developed in the cloud computing paradigm. The main advantages of cloud computing technology include:

- lower requirements for the computing power of users' hardware (the only prerequisite is Internet access);

- reduced costs of ownership and maintenance of hardware and software systems;

- increased accessibility;

- broader opportunities to create new processes and adapt the existing ones to user requirements.
The cloud computing paradigm considers the following as web services: hardware platforms - PaaS (Platform as a Service), databases - DBaaS (Database as a Service), infrastructures - IaaS (Infrastructure as a Service), actual software applications - SaaS (Software as a Service), and more (XaaS - anything as a service) [1]-[3]. Thus, a software application in the cloud computing paradigm, which develops the principles of Service Oriented Architecture (SOA [4]), is considered separately from the hardware and software platform on which it can function.

SOA technology uses the concept of interoperability as the ability of services to interact at different levels. Based on the documents prepared by the European Commission as part of the Interoperable Delivery of European eGovernment Services program and proceeding from the analysis of various standards, Table 1 presents the levels of interoperability and indicates the main software tools used for interoperability that are the standards of SOA.

TABLE I

Levels of interoperability in ascending order (from bottom to top)

\begin{tabular}{|c|c|c|}
\hline $\begin{array}{l}\text { 1) Interoperabilit } \\
\text { y level }\end{array}$ & 2) Characteristic & $\begin{array}{l}\text { 3) Standards and } \\
\text { technologies used }\end{array}$ \\
\hline 4) Regulatory & $\begin{array}{l}\text { 5) Assumes the interaction of } \\
\text { systems in a single regulatory and } \\
\text { legal environment }\end{array}$ & $\begin{array}{l}\text { 6) NIST, OMG, } \\
\text { DMTF }\end{array}$ \\
\hline 7) Organizational & $\begin{array}{l}\text { 8) Refers to organizational } \\
\text { aspects of service operations, } \\
\text { which imply the commonality of } \\
\text { business processes and } \\
\text { regulations of service operations, } \\
\text { legislative acts }\end{array}$ & $\begin{array}{l}\text { 9) UML, BPMN, } \\
\text { MOF }\end{array}$ \\
\hline 10) Semantic & $\begin{array}{l}\text { 11) The ability of services to } \\
\text { uniformly understand the } \\
\text { meaning of the information they } \\
\text { exchange, even if this was not } \\
\text { foreseen when they were created } \\
\text { [5]. }\end{array}$ & $\begin{array}{l}\text { 12) OWL, } \\
\text { RDFS, OWLS, } \\
\text { WSML, RIF, } \\
\text { WSDL-S }\end{array}$ \\
\hline 13) Syntactic & $\begin{array}{l}\text { 14) Ability to integrate. Ability } \\
\text { to exchange data. }\end{array}$ & $\begin{array}{l}\text { 15) UDDI, } \\
\text { SAWSDL, XML, } \\
\text { WSDL }\end{array}$ \\
\hline $\begin{array}{l}\text { 16) Technologi } \\
\text { cal }\end{array}$ & $\begin{array}{l}\text { 17) Organization of interaction } \\
\text { and interconnection. The ability } \\
\text { of services to exchange messages. }\end{array}$ & $\begin{array}{l}\text { 18) TCP/IP, } \\
\text { HTTP, SOAP, } \\
\text { RPC, RMI, MOM }\end{array}$ \\
\hline
\end{tabular}




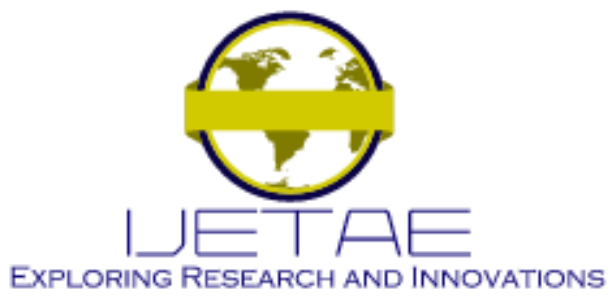

International Journal of Emerging Technology and Advanced Engineering Website: www.ijetae.com (E-ISSN 2250-2459, Scopus Indexed, ISO 9001:2008 Certified Journal, Volume 12, Issue 02, February 2022)

The use of cloud computing technologies makes it possible to create an infrastructure of service-oriented information and educational space (IES). The composition of services for creating individual educational trajectories should be carried out by intelligent agents (semantic brokers), starting from the hardware platform, system software, and database management systems and ending with software applications [6]-[9]. The process of service composition involves the operations of service selection, embedding operations, the definition of input and output messages, and other processes, which should be transparent to users. Detailed descriptions of a composite service must be generated from the composition specification.

Semantics is one of the components most difficult to formalize and, at the same time, a very important one for service composition in terms of assuring that the web services selected for the composition are appropriate and meet the requirements of the resulting composition. An ontology is used to define the semantic characteristics of web services, it is defined as a conceptualization of a particular subject domain [10], [11]. Ontology is a key concept for formally defining semantics and can serve as a basis for semantic process control. Ontologies play a central role in web service composition tasks, extending the syntactic interoperability of services to their semantic interoperability.

Opportunities for service composition at syntactic and semantic levels in cloud computing infrastructure environments can be provided by applying to service descriptions the standards (or their extensions) adopted by the W3C (World Wide Web Consortium): WSDL, SAWSDL, SOAP, UDDI, WSMO, OWL-S (Table 1).

Some standards include references to pre-built ontologies of different levels that contain different concepts (e.g., Service Category in Service Profile of OWL-S). However, the documents of the $\mathrm{W} 3 \mathrm{C}$ pose no requirements to the principles of construction and composition of ontologies. Therefore, the key issues in need of additional research are determining the composition and principles of ontologies to ensure the search and subsequent composition of services of the information and educational space.

\section{METHODS}

In our view, the main objective of accumulating and storing knowledge in the form of an intelligent object repository of the information and educational space (IES) is the development of special tools allowing for automating the process of generating a certain educational program (including individual educational programs).
What appears to be the most appropriate to use as such a toolkit is ontology creation languages that allow describing in detail the structure of each stored object (ontology concept), as well as creating and maintaining semantic links between objects.

Decomposing the main goal of the study, the main stages of our research are as follows [12]:

1. Development of a conceptual model of an intelligent integrated educational environment based on the collection, analysis, classification, and synthesis of information from various sources, including information contained in professional and educational standards.

2. Systematization and organization of elements (concepts) of the model of an intelligent integrated educational environment based on the conjugation of different ontologies as applied to the scope of the model.

3. Formation of an intelligent ontology repository (digital repository) and development on its basis of algorithms and services to generate educational and methodological and organizational and managerial content for specific parameters of the educational environment and requirements for learning outcomes.

Based on the performed analysis of structures and methods of building ontologies, a reasonable conclusion is that it is advisable to include in the ontology used to ensure the semantic interoperability of IES services the concepts that allow describing both the static state and dynamic changes in the states of IES objects. Each concept of ontology is characterized by a certain set of attributes (properties). The mandatory attributes for each concept include the name of the concept, the concept type, materiality ("tangible" (physical)/"intangible" (abstract)), keywords defining the concept, and synonyms.

The types of concepts we use are the following: "Documents", "Participants in the learning process", and "Learning outcomes". Concepts can be linked by the following types of unidirectional or bidirectional links: "Inheritance", "Association", and "Action". The links are also characterized by a set of attributes. The mandatory attributes are the name of the link and the type of the link. Below we provide the main characteristics of concepts and links used to build the specified ontology. 


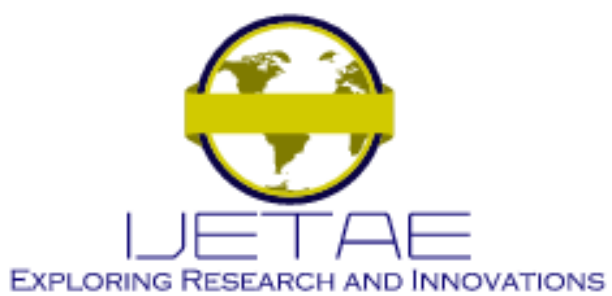

International Journal of Emerging Technology and Advanced Engineering Website: www.ijetae.com (E-ISSN 2250-2459, Scopus Indexed, ISO 9001:2008 Certified Journal, Volume 12, Issue 02, February 2022)

\section{RESULTS}

\section{A. Description of the types of concepts}

Concepts of the "Documents" type are the concepts of ontology that regulate the learning process. Examples of these include: "Professional standard"; "Educational standard"; "Educational program"; "Competency passport"; "Curriculum", etc.

The attributes of the concept "Professional Standard" can be the following: date of approval, code and name of the professional standard, code and name of the type of professional activity, the main purpose of the type of professional activity, codes and names of occupational groups (by the All-Russian Classifier of Occupations), code and name of economic activity (by the All-Russian Classifier of Economic Activities), skill level, codes and names of generalized job functions, codes and names of job functions, knowledge, skills, work actions [13]-[15].

Attributes of the concept "Educational standard" may be the following: code and name of the direction of training (specialty), level of training, areas of professional activity, spheres of professional activity, types of professional tasks, professional tasks, codes and names of universal competencies, codes and names of general professional competencies [16].

The attributes of the concept "Educational program" can be: the date of approval, code and name of the direction of training, level of training, code and name of the profile of training, the term of the educational program, form of training, types of professional tasks, professional tasks, competency matrix, universal competencies, general professional competencies, professional competencies, codes and names of disciplines, modules, practices, requirements to ensure the educational process, other parameters that set the requirements for the educational process.

The attributes of the concept "Competency passport" can include: code and name of competency, type of competency (universal, general professional, professional), codes and names of indicators of competency achievement, codes and names of disciplines forming the competency, learning outcomes for disciplines forming the competency, codes and names of assessment tools that test the formation of the competency through indicators and learning outcomes.
The attributes of the concept "Curriculum" can be the following: the date of approval, code and name of the direction of training, code and name of the training profile, form of training, term of training under the curriculum, codes and names of disciplines, modules, and practices in the curriculum, codes and names of the structural units responsible for disciplines of the curriculum, schedule, matrix distribution of disciplines by year and other time intervals of study, and forms of control for interim attestation for each academic discipline, module, and practice, and forms of control for the final attestation.

Concepts of the type "Participants in the learning process" are the concepts of ontology that interact with each other in the learning process. Examples of these are: "Main enterprises (organizations)", "Educational institutions", "Head of the educational program", "Teacher", "Student", etc.

The attributes of the concept "Main enterprises (organizations)" can be the following: tax ID number and name of the main enterprise, code and name of the type of professional activity, codes and names of groups of occupations (by the All-Russian Classifier of Occupations), codes and names of types of economic activity, codes and names of supervised disciplines and practice modules [13], [14], [17].

The attributes of the concept "Educational institutions" can be: the code and name of the educational institution, codes and names of the areas of training, codes and names of the profiles of training, type of educational institution (school, college, institute, academy, university, etc.), rating of the educational institution, and other parameters.

The attributes of the concept "Head of the educational program" can be as follows: full name of the head, code and name of the direction of training of the educational program they are heading, code and name of the profile of the educational program, the head's academic degree, academic rank, honorary degrees, the educational institution they work in, codes and names of the academic disciplines they teach, codes and names of the branches of science in which the head of the educational program conducts scientific and pedagogical activity, professional (industrial) certificates, certificates of advanced training in the profile of the led educational program, etc. 


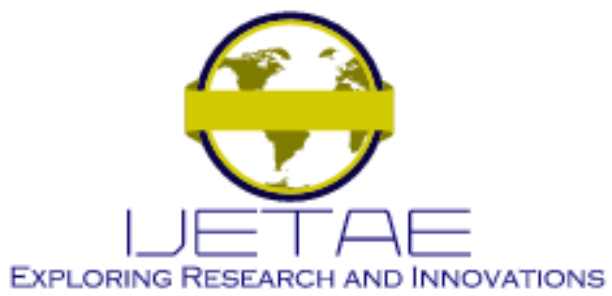

International Journal of Emerging Technology and Advanced Engineering Website: www.ijetae.com (E-ISSN 2250-2459, Scopus Indexed, ISO 9001:2008 Certified Journal, Volume 12, Issue 02, February 2022)

The attributes of the concept "Teacher" may include the following: full name of the teacher, academic degree, academic rank, the educational institution where the teacher works, codes and names of academic disciplines taught by the teacher, codes and names of branches of science in which the teacher conducts scientific and pedagogical activity, professional (industrial) certificates, certificates of advanced training in the profile of the taught disciplines, etc.

Attributes of the concept "Student" can be: code of the student (if any), full name of the student, date of birth, gender, code and name of the institution, code and name of the direction of training, code and name of the profile of training, code and name of the form of training, etc.

Concept type "Learning outcomes" includes the concepts of "Competencies"; "Mastered disciplines"; "Student portfolio", etc.

Attributes of the concept "Competencies" can include: the student's identification number, full name, code and name of the institution, code and name of the direction of training, code and name of the profile of training, code and name of the curriculum, codes and names of competencies mastered by the students in this direction and profile of training within the curriculum.

The attributes of the concept "Mastered disciplines" can be: the student's identification number, full name of the student, code and name of the institution, code and name of the direction of training, code and name of the training profile, code and name of the curriculum, codes and names of the mastered disciplines with the corresponding learning outcomes (grades).

Attributes of the concept "Student portfolio" may include: the student's identification number, full name of the student, code and name of the institution, code and name of the direction of training, code and name of the profile of training, rating of the student (according to the point-rating student performance assessment system), codes and names of places of internship of the student with the results (grades), codes and names of the branches of science, in which the student has achievements (awards) for participation in conferences and other events, professional certificates in the direction and profile of training, reviews of internship supervisors, reviews of scientific advisors, other documents related to the learning, research, and professional activities of the student [18].

\section{B. Description of the types of links}

The "Association" type of links is analogous to the links between entities of the conceptual level in database design.
It has the attribute of "Linkage power" (1:1, 1:M, M:M). For example, one "Student" studies different "Disciplines", one discipline is studied by different "Students" (attribute "Linkage Power" takes the value M:M). One "Student" gets an internship at one "Main enterprise (organization)", different students get an internship at one "Main enterprise (organization)" (the "Linkage power" attribute takes the value $\mathrm{M}: 1)$.

Links of the "Action" type are used when creating a new object based on an existing one or changing the value of object attributes (typically the state of the object), as a result of which one or more goals are achieved. Links of the "Action" type are referred to as verbs (attribute "Link name"). An example of their usage can be the following: the concept "Competency" is tied with the "Action" type of link(with the attribute "Link name" being "Formed") to the concept "Discipline".

Links of the "Inheritance" type allow describing a new object class based on an existing (parent) class with the attributes of the parent class being borrowed by the new class. This type of link is analogous to "Genus-Species" and "Integer-Private" relationships. For example, the concept "Educational institution" is connected with the "Inheritance" type of link with the concepts "University", "School", "Academy".

\section{DISCUSSION}

Studies of both Russian and foreign scholars [9]-[11] indicate that the provision of semantic interoperability of educational services is associated with the need to employ concept ontologies, which are used in the processes of IES functioning and describe them.

However, it needs to be noted that the current research on the semantic interoperability of services is somewhat scattered. In particular, the structure of ontologies (types of concepts, types of links, attributes) to be used specifically to provide semantic interoperability of educational services is currently not defined. The importance of unifying the structure of ontologies for solving a particular class of problems is pointed out, for example, in the work of L.V. Naikhanova [19] devoted to the construction of ontologies for extracting knowledge from scientific texts. The monograph gives a description of the composition of concept ontologies, the types of links between concepts, and algorithms of automatic construction of such ontologies. Similar work to determine the ontology structure needs to be carried out with respect to the ontologies planned to be used to provide semantic interoperability of educational services. 


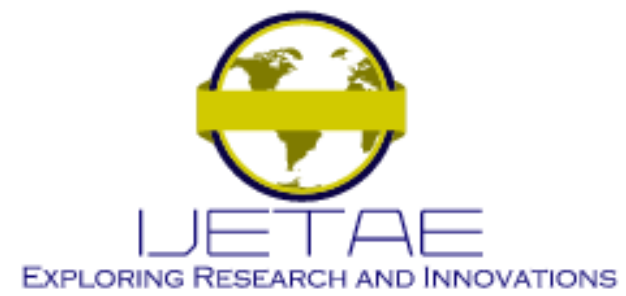

International Journal of Emerging Technology and Advanced Engineering Website: www.ijetae.com (E-ISSN 2250-2459, Scopus Indexed, ISO 9001:2008 Certified Journal, Volume 12, Issue 02, February 2022)

To solve the problems of semantic interoperability, it is necessary to secure the possibility of shared use of the ontologies of the interacting services. For this purpose, a generalized ontology, which is a logical union of ontologies, is usually built. In the study by P.A. Lomov and M.G. Shishaev [20], it is pointed out that the integration of ontologies requires unifying not only their structure but also the algorithms of their construction. Otherwise, in the process of adding a new concept to the united ontology and creating for it a new ontological description (attributes, connections), there may arise conflicts due to the different points of view on a certain concept in different ontologies (for example, the level at which the concept and its environment are). Different types of conflicts and ways to resolve them are described, for example, in the works of IU. F. Telnov and his co-authors [8]-[11].

Currently, there already exist algorithms and their software implementations for automatic integration of ontologies. Information about such algorithms is provided, for example, by D.G. Korneev, M.S. Gasparian, and A.A. Mikriukov [12]. Each of the currently existing algorithms for automatic integration of ontologies, along with the advantages, has several significant drawbacks. The disadvantages are primarily associated with the insufficient unification of the structures of integrated ontologies, which describe the concepts of one subject area but have different structures and algorithms of their initial construction. In light of the above, the present study develops approaches to creating a unified structure of ontologies for information and educational services to be used to ensure the interoperability of IES services.

\section{CONCLUSION}

As a result of the research, a possible structure (a set of types of concepts and links) of ontology for solving problems related to the provision of semantic interoperability of IES services is described. In the future, it is planned to test the specified structure in practice. Based on the results of the testing, the described ontology structure will be refined and possibly supplemented with new objects and links.

The practical significance of the study is due to the developed approaches to creating service-oriented IES. The obtained results will allow creating services with more intelligently developed means of interaction. The results of the research on semantic interoperability will provide the opportunity to improve the intellectual component of services, which will allow solving a wider range of intellectual tasks.

\section{Acknowledgments}

The authors express their gratitude to the Russian Foundation for Basic Research for support in the preparation of this article (grants № 20-07-00926 and № 19-07-01137).

\section{REFERENCES}

[1] Martin, D., Burstein, M., Hobbs, J., Lassila, O., McDermott, D., McIlraith, Sh., Narayanan, S., Paolucci, M., Parsia, B., Payne, T., Sirin, E., Srinivasan, N., and Sycara, K. 2004. OWL-S: Semantic Markup for Web Services. Available at: http://www.w3.org/Submission/2004/SUBM-OWL-S-20041122/

[2] Chinnici, R., Canon J-J. M., Ryman, A., and Weerawarana, S. W3C Web Services Description Language (WSDL). Available at: http://www.w3.org/TR/wsdl

[3] Akkiraju, R., Farrell, J., Miller, J., Nagarajan, M., Schmidt, M. Th., Sheth, A., and Verma, K. 2005. Web Service Semantics - WSDL-S. Available at: https://www.w3.org/Submission/WSDL-S/

[4] Tversky A. 1997. Features of similarity. Psychological Rev., 84, 327.

[5] Khokhlov, E. (ed). 2009. Glossarii po informatsionnomu obshchestvu [Glossary on the Information Society]. Moscow: Institute of the Information Society.

[6] Rada, R., Mili, H., Bicknell, E., and Blettner, M. 1989. Development and application of a metric on semantic nets. IEEE Trans. Syst. Man Cybern., 19, 17-30.

[7] Leacock C., and Chodorow M. 1998. WordNet: An electronic lexical database. Cambridge.

[8] Telnov, IU.F., Kazakov, V.A., and Danilov, A.V. 2012. Formalizatsiia vzaimodeistviia servisov i agentov dinamicheskoi intellektualnoi sistemy upravleniia biznes-protsessami [Formalization of interaction between services and agents of a dynamic intelligent business process management system]. Sci. Practical J. Open Educ., 1.

[9] Telnov, Iu. F., Danilov, A. V., and Kazakov, V.A. 2010. Servisnoorientirovannaia arkhitektura dinamicheskoi intellektualnoi sistemy upravleniia biznes-protsessami [Service-oriented architecture of a dynamic intelligent business process management system]. Sci. Practical J. Open Educ., 6.

[10] Telnov, Iu. F., Kazakov, V. A., Kozlova, O. A. 2013. Dinamicheskaia intellektualnaia sistema upravleniia protsessami v informatsionno-obrazovatelnom prostranstve vysshikh uchebnykh zavedenii [Dynamic intelligent system of process management in the information and educational space of higher education institutions]. Sci. Practical J. Open Educ., 1.

[11] Mädche, A., Stojanovic, N., Staab, S., Studer, R., and Sure, Y. 2001. SEAL: a framework for developing SEmantic portALs. 1st International Conference on Knowledge Capture (K-CAP), Victoria, BC, Canada, 21-23 October 2001, 155-162. DOI: 10.1145/500737.500762

[12] Korneev, D.G., Gasparian, M.S., and Mikriukov, A.A. 2019. Ontologicheskii podkhod $\mathrm{k}$ modelirovaniiu innovatsionnykh protsessov na primere raspredelennoi obrazovatelnoi seti vuza [Ontological approach to innovative process modeling on the example of a distributed educational network of a university]. Sci. Practical J. Open Educ., 23(5), 4-13. 


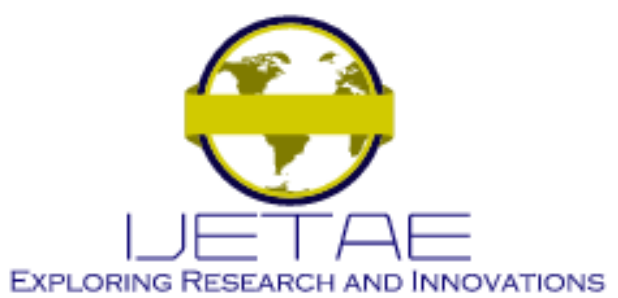

International Journal of Emerging Technology and Advanced Engineering

Website: www.ijetae.com (E-ISSN 2250-2459, Scopus Indexed, ISO 9001:2008 Certified Journal, Volume 12, Issue 02, February 2022)

[13] Ministry of Labor and Social Protection of the Russian Federation, and Federal Agency for Technical Regulation and Metrology. 2014. OK 010-2014 (MSC-08). All-Russian Classifier of Occupations (adopted and enacted by Order of Rosstandart of December 12, 2014, N 2020-st).

[14] Ministry of Labor and Social Protection of the Russian Federation, and Federal Agency for Technical Regulation and Metrology. 2017. OK 029-2014 (KDES Ed. 2). All-Russian Classifier of Types of Economic Activities (approved by Order of Rosstandart of January 31, 2014, N 14-st) (ed. from September 8, 2017).

[15] Ministry of Labor and Social Protection of the Russian Federation. 2017. Uniform Qualification Reference book of the positions of managers, specialists, and other employees (EKS).

[16] Federal Agency for Technical Regulation and Metrology. 2016. OK 009-2016. All-Russian Classifier of Specialties in Education (adopted and enacted by the Order of Rosstandart of December 8, 2016, N 2007-st).
[17] Ministry of Economic Development of the Russian Federation, and Federal Service of State Statistics. 2021. OK 007-93. All-Russian Classifier of Enterprises and Organizations (ed. from April 13, 2021).

[18] Federal Agency for Technical Regulation and Metrology. 2020. OK 017-2013 All-Russian Classifier of Specialties of Higher Scientific Qualification (adopted and enacted by Order of Rosstandart of December 17, 2013, N 2255-st, edition of June 23, 2020, including amendments entered into force on July 1, 2020).

[19] Naikhanova, L. V. 2018. Tekhnologiia sozdaniia metodov avtomaticheskogo postroeniia ontologii $\mathrm{s}$ primeneniem geneticheskogo i avtomatnogo programmirovaniia [Technology for the creation of methods of automatic construction of ontologies using genetic and automata-based programming]. Ulan-Ude: Publishing House of the Buryat Scientific Centre of Siberian Department of Russian Academy of Sciences.

[20] Lomov, P. A., and Shishaev, M. G. 2019. Integratsiia ontologii s ispolzovaniem tezaurusa dlia osushchestvleniia semanticheskogo poiska [Integration of ontologies using a semantic search thesaurus]. Inf. Tech. Comp. Syst., 4. 